\title{
An AHP-derived method for mapping the physical vulnerability of coastal areas at regional scales
}

\author{
G. Le Cozannet ${ }^{1}$, M. Garcin ${ }^{1}$, T. Bulteau ${ }^{1}$, C. Mirgon $^{1}$, M. L. Yates ${ }^{1, *}$, M. Méndez ${ }^{1,2,{ }^{* *}}$, A. Baills ${ }^{1}$, D. Idier ${ }^{1}$, and \\ C. Oliveros ${ }^{1}$ \\ ${ }^{1}$ BRGM, 3 Avenue Claude Guillemin Cedex 2, BP 6009, 45060 Orléans, France \\ ${ }^{2}$ University Diderot-Sorbonne Paris, 75205 Paris Cedex 13, France \\ * now at: Université Paris-Est, Laboratoire d'Hydraulique Saint-Venant, ENPC, EDF R\&D, CETMEF, 6 quai Watier, BP 49, \\ 78401 Chatou, France \\ ** now at: University Rafael Landivar de Guatemala, Institute of Agriculture, Natural Resources and the Environment, \\ IARNA/URL, Vista Hermosa 3, Guatemala
}

Correspondence to: G. Le Cozannet (g.lecozannet@brgm.fr)

Received: 15 October 2012 - Published in Nat. Hazards Earth Syst. Sci. Discuss.: Revised: 18 March 2013 - Accepted: 20 March 2013 - Published: 16 May 2013

\begin{abstract}
Assessing coastal vulnerability to climate change at regional scales is now mandatory in France since the adoption of recent laws to support adaptation to climate change. However, there is presently no commonly recognised method to assess accurately how sea level rise will modify coastal processes in the coming decades. Therefore, many assessments of the physical component of coastal vulnerability are presently based on a combined use of data (e.g. digital elevation models, historical shoreline and coastal geomorphology datasets), simple models and expert opinion. In this study, we assess the applicability and usefulness of a multi-criteria decision-mapping method (the analytical hierarchy process, AHP) to map physical coastal vulnerability to erosion and flooding in a structured way. We apply the method in two regions of France: the coastal zones of Languedoc-Roussillon (north-western Mediterranean, France) and the island of $\mathrm{La}$ Réunion (south-western Indian Ocean), notably using the regional geological maps. As expected, the results show not only the greater vulnerability of sand spits, estuaries and lowlying areas near to coastal lagoons in both regions, but also that of a thin strip of erodible cliffs exposed to waves in La Réunion. Despite gaps in knowledge and data, the method is found to provide a flexible and transportable framework to represent and aggregate existing knowledge and to support long-term coastal zone planning through the integration of such studies into existing adaptation schemes.
\end{abstract}

\section{Introduction}

The attraction of coastal zones has greatly increased in the last hundred years. As a result, people and infrastructure have become more exposed to coastal hazards, including marine erosion and submersion, and the costs of protection have increased accordingly. A European assessment under the Eurosion project (2004) found that 3.2 billion euros were spent on stabilising European shorelines in 2001. Given this context, sea level rise is expected to aggravate a wide range of already existing coastal hazards (Nicholls and Cazenave, 2010).

Mitigating and preventing coastal risks often relies on protection measures. For example, in Languedoc-Roussillon, hard defence structures such as groynes and breakwaters have been placed along the coast in order to reduce erosion and submersion risks. However, whether these protective measures can be sustained in the long term remains an open question. The legislation in France therefore requires regional authorities to develop adaptation strategies designed for longer timescales than these protective measures, which are expected to be efficient for a few decades. This requires assessments of longer term coastal zone physical vulnerability to marine erosion and submersion over time frames that incorporate the effects of climate change. "Physical vulnerability" refers here to the "sensitivity of the physical environment, of coastal areas themselves" to erosion and submersion in the context of climate change (Romieu et al., 2010), and 
mapping it is far from straightforward (e.g. Preston et al., 2011).

In shallow coastal waters, waves and currents can cause sediment transport and bathymetry changes (i.e. sea floor topography), which in turn affect waves and currents (e.g. Coco and Murray, 2007). On time scales longer than several weeks, all of these processes cannot be modelled with sufficient accuracy for long-term analysis. Therefore, longer term studies attempt to quantify sediment transport processes in a simplified way either in the cross-shore and/or longshore direction (Hanson et al., 2003) as gradients in longshore sediment transport may be the result in erosion or accretion. It is worth noting that these morphosedimentary dynamic processes are also important for anticipating potential future marine submersion because nearshore waves and sea level depend on offshore atmospheric and marine conditions, as well as of the bathymetry.

However, it is still possible to appraise long-term morphosedimentary dynamics by analysing a number of coastal features, including coastal geomorphology (e.g. Cooper and Jay, 2002), exposure to waves and currents, local sedimentary budgets (potentially affected by human activities), and relative sea level variations. At regional scales, Gornitz et al. (1991) developed an approach in which data describing these components of physical vulnerability assessments are aggregated. The resulting coastal vulnerability index (CVI) originally took into account the following data: historical erosion rates, nearshore slope, tidal amplitude, observations and predictions of sea level variations, wave climate, and coastal geomorphology (Gornitz et al., 1991). Some adaptations of the CVI benefited from other data and put more emphasis on, for example, coastal subsidence as a component of relative sea level rise (e.g. Doukakis, 2005). Beyond qualitative assessments of coastal vulnerability (e.g. Paskoff, 2004; Lebbe et al., 2008; Alpar, 2009), the challenge in mapping coastal vulnerability is to combine all of this heterogeneous information into one single map in a structured way, and to appropriately integrate the opinion of experts when data are insufficient to directly solve the problem (e.g. Fairbanks and Jakeways, 2006; Vinchon et al., 2009; Hanson et al., 2010).

In this study, we describe a new method for mapping coastal vulnerability that incorporates expert analysis, and qualitative and quantitative data in a more structured way. The method is based on a multi-criteria decision-mapping method (Malczewski, 2006; Chakar, 2006) - the analytical hierarchy process (AHP; Saaty, 1980; part 2). We integrate AHP into a complete coastal physical vulnerability mapping method and apply it in two regions of France: the island of La Réunion in the south-western Indian Ocean and Languedoc-Roussillon in the Mediterranean (part 3). We provide new maps of coastal vulnerability in the two regions as a result (part 4). We discuss the advantages, limitations, and transportability of the proposed method, and investigate its potential to be integrated into emerging adaptation practices in France (part 5).
Table 1. The fundamental scale of absolute numbers ("Saaty scale", adapted from Saaty, 2008a)

\begin{tabular}{ll}
\hline $\begin{array}{l}\text { Intensity of } \\
\text { importance }\end{array}$ & Definition \\
\hline 1 & Equal importance of both components \\
\hline 3 & $\begin{array}{l}\text { Judgement slightly favours one } \\
\text { component over another (moderate } \\
\text { difference of importance) }\end{array}$ \\
\hline 5 & $\begin{array}{l}\text { Judgement strongly favours one } \\
\text { component over another (strong } \\
\text { difference of importance) }\end{array}$ \\
\hline 7 & $\begin{array}{l}\text { Very strong or demonstrated } \\
\text { importance of one component } \\
\text { with respect to another. }\end{array}$ \\
\hline 9 & $\begin{array}{l}\text { Evidence of extreme difference of } \\
\text { importance of one component } \\
\text { with respect to another. }\end{array}$ \\
\hline
\end{tabular}

\section{The AHP process}

\subsection{The AHP process}

The analytical hierarchy process (Saaty, 1980) is a multicriteria decision analysis method that solves decision-making problems by ranking alternatives according to several criteria. The main steps in the method involve (Saaty, 2008a):

- representing a decision-making problem by organising its criteria into a hierarchical structure,

- evaluating the relative importance of the criteria (within a hierarchical tree) and then the alternatives with respect to each criterion; this is done by constructing pairwise comparison matrices of criteria and alternatives regarding each criterion. For example, a simple decision problem with 3 criteria and 5 alternatives will require one $3 \times 3$ comparison matrix to be built for the criteria weighting and three $5 \times 5$ comparison matrices for evaluating the alternative criteria, and

- synthesising the analysis by calculating the weighted sum of scores for alternatives based on the weights of their parent nodes in the hierarchical tree.

The pairwise comparisons of criteria are made using a scale of absolute judgements, commonly called Saaty's scale, which indicates by how much one item predominates over another with respect to a given attribute. This scale transforms qualitative evaluations into numerical values from 1 to 9 (Table 1), which are used to fill in the pairwise comparison matrices. The priority scales are then derived by calculating the eigenvector associated with the principal eigenvalue of each comparison matrix (Saaty, 1980). When the priority 
Table 2. Pairwise comparison of three zones with respect to their potential to be eroded in 2100 with a hypothesis of no sea level rise, following Saaty (2008a). The numerical values in the matrix are directly those from "Saaty's scale" (Table 1). Experts filled the bold numerical values. For example, the numerical value " 5 " (line 1, column 2) indicates that the judgement strongly favours that Z1 is more likely to be eroded than Z2 in 2100. "9" in column 3 indicates that there is extreme evidence that Z3 is more likely to erode than Z1. The resulting index provides the final scores obtained for each zone (Z1, Z2, and Z3) with respect to the criterion "potential to be eroded in 2100 ". It is calculated by "raising the pairwise comparison matrix to large powers, summing each row and dividing each by the total sum of all rows" (Saaty, 2008a, see Sect. 2.3).

\begin{tabular}{lllll}
\hline & $\begin{array}{l}\text { Z1: Zone "likely to } \\
\text { be eroded by 2100": } \\
\text { located within } \\
\text { extrapolated } \\
\text { observed trend }\end{array}$ & $\begin{array}{l}\text { Z2: Zone "possibly } \\
\text { eroded by 2100": } \\
\text { located within twice } \\
\text { the extrapolated } \\
\text { observed trend }\end{array}$ & $\begin{array}{l}\text { Z3: Zone "unlikely to } \\
\text { be eroded by 2100": } \\
\text { other areas }\end{array}$ & $\begin{array}{l}\text { Resulting index } \\
\text { using AHP }\end{array}$ \\
\hline Z1 & 1 & $\mathbf{5}$ & $\mathbf{9}$ & 0.7352 \\
Z2 & $1 / 5$ & 1 & $\mathbf{5}$ & 0.2067 \\
Z3 & $1 / 9$ & $1 / 5$ & 1 & 0.0581 \\
\hline
\end{tabular}

scales in the matrix are consistent, the normalised eigenvector is unique and equal to any normalised column of the matrix. However, sometimes, and especially when many comparisons are involved, the judgements may be inconsistent. In this case, the priority scales can still be derived by solving the eigenvalue problem, the eigenvector being an approximation of the ideal case (Saaty, 2008b, Sekitani and Yamaki, 1999). The method also provides a framework for evaluating the consistency of the judgements (Saaty, 2008a).

\subsection{AHP in decision mapping problems}

In multi-criteria decision-mapping problems, alternatives might be geographical entities or landforms, while the criteria may be those that help to evaluate, for example, a level of risk or vulnerability. There are numerous examples of the use of AHP mapping problems in previous studies. In the field of hazard and risk zoning, it has been used to map landslide hazard and susceptibility (e.g. Ayalew et al., 2005; Gorsevski et al., 2006; Yalcin, 2008; Ercanoglu et al., 2008), soil erosion hazard mapping (Rahman et al., 2009), earthquake hazard zoning (Pal et al., 2008), and flood mapping (Nguyen Mai et al., 2011; Chen et al., 2011). For coastal risks, Chang et al. (2012) applied the method to rank different coastal protection options. However, the only application of AHP that we found for physical coastal vulnerability assessments in the context of climate change was the study by Yin et al. (2012), which produced a national assessment of coastal vulnerability in China by adapting a CVI approach in which the variables were weighted with AHP.

\subsection{Fundamental principle of applying AHP to mapping coastal vulnerability}

In the coastal vulnerability mapping problems, there is relatively abundant (but non-exhaustive) data (observations, simple models, and expert opinions) that may describe one component of physical vulnerability. For example, a geological map provides information about lithology and thus sensitivity to erosion; similarly, past shoreline changes and simplified models may be used to anticipate future erosion. Our approach simply consists of using the AHP to translate this information from experts, simple models, and data into comparable quantitative data and to aggregate this data into a single multi-criteria mapping framework.

In practice, the approach consists of using Table 1 as a reference for completing pairwise comparisons of different areas with respect to each other and to each criterion. For example, by applying a simple model of shoreline change such as the Bruun rule or the extrapolation of previously measured rate of change, we can define a mean shoreline change rate from now to 2100 and define three zones:

- (Z1) areas eroded in 2100 according to the simplified model,

- (Z2) areas eroded if the actual rate of erosion is twice the rate according to the simplified model, and

- (Z3) other locations, i.e. area located farther inland from zones $\mathrm{Z} 1$ and $\mathrm{Z} 2$.

Here, a group of coastal experts made the subjective choice to use twice the rate of observed erosion to define areas that will likely be eroded by 2100 . Using Saaty's scale, experts may agree that their "judgement strongly supports the idea that" area (Z1) is more likely to be eroded than (Z3). This judgement corresponds to a 5 in Saaty's scale and is inserted in Table 2. Similarly, there is "evidence of extreme difference of importance" between areas (Z1) and (Z3). Therefore, the numerical value 9 is used in Table 2. The resulting indexes are calculated according to the AHP method.

The next section explains how we have incorporated this simple idea into a complete approach by replicating these pairwise comparisons for all components accounting for the physical vulnerability. 


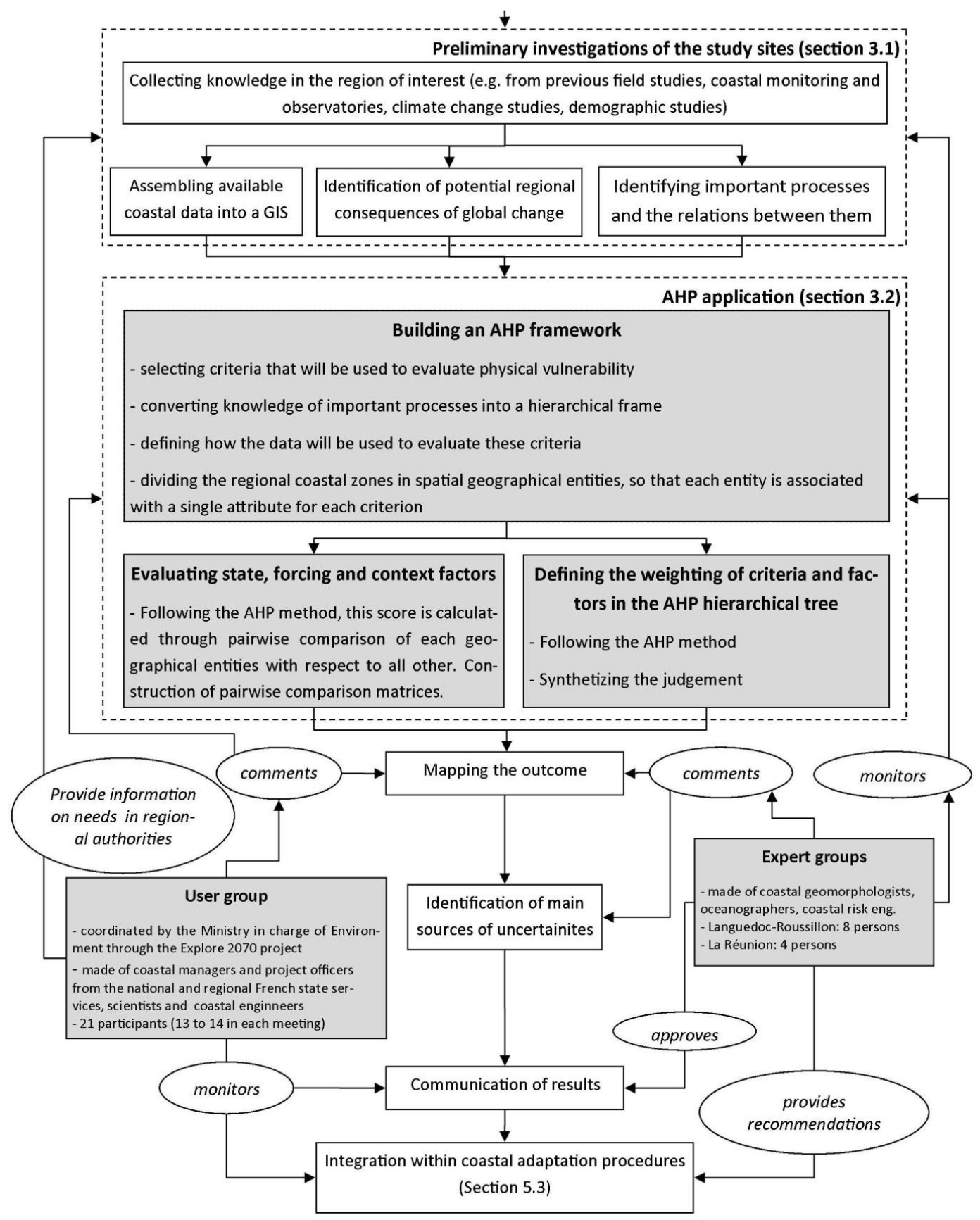

Fig. 1. Sequential process used in this study to produce and validate physical vulnerability maps.

\section{Method application at the study sites}

We summarise the sequential method used in this paper for evaluating coastal physical vulnerability in Fig. 1. We start with preliminary investigations at the coastal sites and global change consequences on existing coastal processes (3.1), and then apply a complete approach that integrates a number of important criteria contributing to physical coastal vulnerability (3.2).

\subsection{Preliminary investigations in the study sites}

\subsubsection{Site description}

We apply the method in two regions of France with different climatic conditions, geomorphology, and data availability: La Réunion in the south-western tropical Indian Ocean and Languedoc-Roussillon along the western Mediterranean coast. 
Table 3. Summary of data sources used in this study.

\begin{tabular}{|c|c|c|c|c|}
\hline \multirow[t]{2}{*}{ Data } & \multicolumn{2}{|c|}{ Languedoc-Roussillon } & \multicolumn{2}{|c|}{ La Réunion } \\
\hline & Data source & Description/Comment & Data source & Description/Comment \\
\hline $\begin{array}{l}\text { Coastal } \\
\text { geomorphology }\end{array}$ & Eurosion (2004) & $\begin{array}{l}\text { 1:100000 description } \\
\text { of geomorphology and } \\
\text { erosion trends }\end{array}$ & $\begin{array}{l}\text { BRGM: De La } \\
\text { Torre (2004) } \\
\text {; De La Torre et } \\
\text { al. (2006); Blangy et } \\
\text { al. (2010) }\end{array}$ & $\begin{array}{l}\text { Local description of } \\
\text { geomorphology and } \\
\text { erosion trends }\end{array}$ \\
\hline $\begin{array}{l}\text { Observed } \\
\text { erosion trends }\end{array}$ & $\begin{array}{l}\text { DREAL data } \\
\text { reinterpreted by } \\
\text { Yates et al. (2011) }\end{array}$ & $\begin{array}{l}\text { Local rates of observed } \\
\text { past erosion }\end{array}$ & $\begin{array}{l}\text { De La Torre et } \\
\text { al. (2006) }\end{array}$ & $\begin{array}{l}\text { Sparse data from some } \\
\text { representative sites }\end{array}$ \\
\hline Geology & BRGM & $\begin{array}{l}1: 50000 \text { Vectorised } \\
\text { geological map }\end{array}$ & BRGM & $\begin{array}{l}1: 50000 \text { Vectorised } \\
\text { geological map }\end{array}$ \\
\hline $\begin{array}{l}\text { Digital } \\
\text { elevation model }\end{array}$ & $\begin{array}{l}\text { Geographic } \\
\text { institute (IGN) }\end{array}$ & $\begin{array}{l}50 \mathrm{~m} \text { horizontal } \\
\text { resolution grid }\end{array}$ & IGN data & $\begin{array}{l}10 \mathrm{~m} \text { horizontal } \\
\text { resolution grid }\end{array}$ \\
\hline Land use & $\begin{array}{l}\text { Corine Land Cover } \\
\text { (European Environment } \\
\text { Agency) }\end{array}$ & $\begin{array}{l}1: 100000 \text { land cover } \\
\text { description }\end{array}$ & / & / \\
\hline $\begin{array}{l}\text { Hydrographic } \\
\text { network }\end{array}$ & BD Carthage (IGN) & $\begin{array}{l}\text { 1:50000 description of } \\
\text { watersheds }\end{array}$ & BD Carthage & l \\
\hline $\begin{array}{l}\text { Exposure to } \\
\text { waves climates } \\
\text { and eventually } \\
\text { cyclones }\end{array}$ & $\begin{array}{l}\text { DREAL Languedoc } \\
\text { Roussillon }\end{array}$ & $\begin{array}{l}\text { Recommendations for } \\
\text { setting coastal risks } \\
\text { prevention plans }\end{array}$ & Lecacheux et al. (2012) & $\begin{array}{l}\text { Exposure to cyclonic, } \\
\text { southern and eastern } \\
\text { waves }\end{array}$ \\
\hline
\end{tabular}

La Réunion is a volcanic island whose base lies $4000 \mathrm{~m}$ deep on the ocean floor. Its coastline is $250 \mathrm{~km}$ in length and its coastal geomorphology is dominated by volcanic rocks and pebble beaches (De La Torre, 2004). The coastal zone is nourished by alluvial sediments, particularly near the estuaries of large rivers. The island is located in a region impacted by cyclones, as well as southern swell. Finally, especially in the east, the island's very high precipitation enhances sediment transport in rivers, nourishing the coast with alluvial sediments in the vicinity of some estuaries (Garcin et al., 2005). Beaches are thus composed of volcanic materials, but also of biodetritic sand in the south-west, where a fringing reef has developed.

The coast of Languedoc-Roussillon mainly consists of sandy beaches, with some rocky outcrops of Cenozoic basalts and limestone (Agde, Cap Leucate) or Mesozoic limestone (Sète). To the south, near Spain, the coast features Paleozoic rock cliffs with pocket beaches. Earlier studies (Vinchon et al., 2009) have concluded from a previous analysis that coastal risks in this region would worsen with climate change.

\subsubsection{Available data}

The two regions differ considerably in terms of data availability (Table 3): in Languedoc-Roussillon, public data are very heterogeneous, with some inconsistencies in various shoreline datasets' positioning (Yates-Michelin et al., 2011). We used the data collected and acquired by the DREALLR (the regional agency of the national Environment Ministry in Languedoc Roussillon) to calculate shoreline change rates over the entire region. On the other hand, while shoreline positioning in La Réunion was found to be mostly consistent between the various geographical data sources, information on erosion rates only exists at a few particular sites (De la Torre et al., 2006).

Using lidar data available along a $20 \mathrm{~km}$ stretch of shoreline in the northern part of the Gulf of Lion, Yates et al. (2011) evaluated the vertical precision $(1.27 \mathrm{~m})$ and accuracy $(0.16 \mathrm{~m})$ of available digital elevation model (DEM). In La Réunion this could not be quantified, but a comparison with topographical maps suggests that the available data are of similar quality.

Geological maps represent the superficial geological formations based on an interpretation of field observations. The limits of use of digital vectorised geological maps are related to their scale (1:50000), and, in addition, they do not 


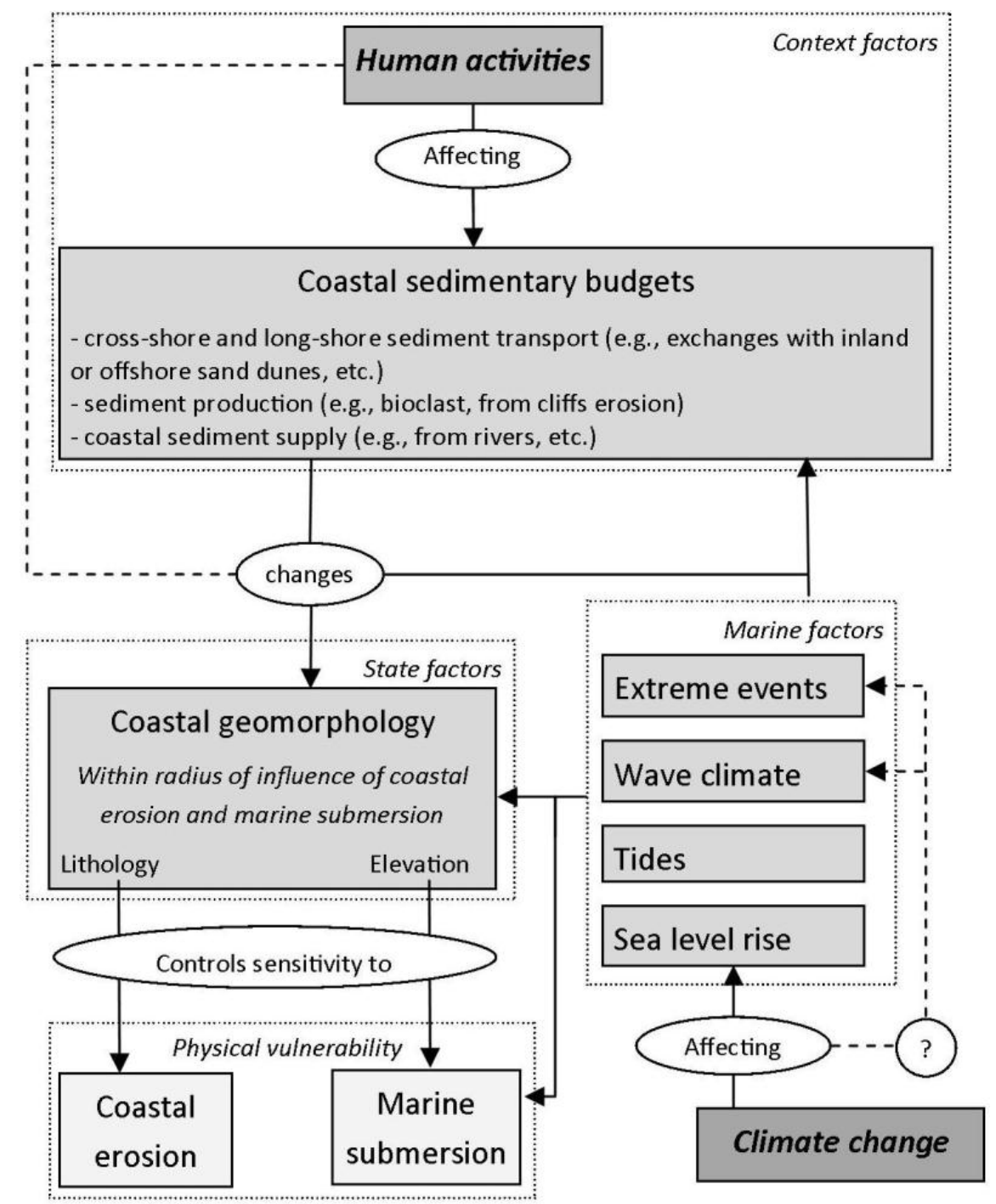

Fig. 2. Simplified diagram of the interactions between various factors controlling the physical vulnerability of coastal areas.

highlight if a formation has been observed or interpreted by a geologist. In the two regions, the late Quaternary (Holocene) deposits are sufficiently well detailed to use this information in coastal areas.

\subsubsection{Regional consequences of global change and sea level scenarios}

While the future consequences of global change in both regions are still largely uncertain, it is possible to identify a number of trends that suggest some possible future outcomes. In both regions, human use of the coastal area increased drastically during the second half of the 20th century (e.g. Deboudt, 2010; Cazes-Duvat and Paskoff, 2004). However, current regulations and coastal risk prevention plans prevent unlimited urbanisation of the seafront. In this study, we assumed that any further coastal urbanisation would occur farther inland and did not consider their potential effects on shoreline change (e.g. through the construction of new coastal defences).

In this study, we found that there is insufficient knowledge about future changes in waves, storms, and precipitation at the study sites to take into account their effects on coastal processes. Therefore, we only considered changes due to future sea level rise. Estimates of sea level rise in 2100 range from about $0.5 \mathrm{~m}$ (Meehl et al., 2007) to roughly $1 \mathrm{~m}$ (e.g. Rahmstorf, 2007), with the main source of uncertainty being the future contribution of melting processes in Greenland and the western Antarctic ice sheets. Sea level changes vary regionally not only because of non-uniform warming of the ocean and variations in salinity (e.g. Lombard et al., 2005; Meyssignac and Cazenave, 2012), but also because of 
changes in the gravitational field due to the redistribution of ice and water masses (Slangen et al., 2012) and subsidence or uplift potentially affecting the coastal zone at various scales (e.g. Wöppelmann et al., 2007). Therefore, although Slangen et al. (2012) developed a method for predicting all of the components of future regional sea level rise, local projections are still uncertain. In particular, in our case studies, the potential vertical ground motions are insufficiently known (data available from www.sonel.org). Moreover, in the particular case of the Mediterranean Sea, it is worth noting that using a single climate scenario, Tsimplis et al. (2008) showed that thermosteric effects may not cause any sea level rise along the French Mediterranean coast.

These few examples support the idea that several sea level scenarios should be considered in regional assessments of the effects of future sea level rise. In this study, we considered two extremely contradictory sea level scenarios for the end of the 21st century:

- a $1 \mathrm{~m}$ sea level rise scenario by 2100 (called the "sea level rise scenario" hereafter),

- a scenario in which current processes (e.g. erosion) are assumed to continue as in the recent past, without being significantly affected by sea level rise ("trend scenario").

The "sea level rise" scenario is consistent with results of semi-empirical studies (e.g. Rahmstorf, 2007). It may also result from a combination of moderate global sea level change superimposed with regional variability. The second scenario may result of regional variability in future relative sea level rise, but it is primarily designed for analysing how coastal vulnerability may change even without sea level rise (see Sect. 5.1). These two scenarios are intended to provide contradictory hypotheses with which to test the robustness and reversibility of adaptation measures.

\subsubsection{Identification of important processes and the rela- tions between them}

Using the knowledge and data described above, we have built up a scheme (Fig. 2) of the various factors that control vulnerability in the coastal system and their interactions. These factors were grouped into the following:

- state factors, describing how coastal erosion and marine submersion relates to the local geomorphology, i.e. lithology along coastal strips, elevation, and current sedimentary balance as revealed by observations of past erosion;

- marine factors, describing how each location is exposed to sea waves and surges, e.g. during an easterly storm in Languedoc-Roussillon or during a cyclone or southern wave event in La Réunion;
- context factors, describing how physical vulnerability in a specific location may be increased or decreased due to the influence of nearby geomorphological systems; for example, a beach located near to a major estuary may be nourished with sediments, thus preventing or reducing erosion.

Figure 2 is a simplified scheme of the functioning of the coastal zone, which can be applied to a wide range of coasts, at least those considered in this study.

\subsection{AHP application}

This section describes how we set up the method in $\mathrm{La}$ Réunion and in Languedoc-Roussillon (Fig. 1). We use ArcGIS for the geoprocessing and Matlab for the AHP calculations.

\subsubsection{Building up the AHP framework}

Using the preliminary investigations, we convert the general conceptual tree developed during the preliminary investigations (Fig. 2) into an AHP-suitable hierarchical scheme (Fig. 3), which organises the various criteria that are used to evaluate the physical vulnerability. Then, we determine the approximate radius of influence of coastal erosion and submersion (Eurosion, 2004), which we divide into elementary geographical entities, ensuring that each entity is related to a single combination of factors accounting for its physical vulnerability. We determine these elementary geographical entities by intersecting existing data, simple laws and hypotheses (e.g. by cross-tabulating reference storm surge levels with a DEM, inferring susceptibility to erosion from a geological map, etc.).

\subsubsection{Evaluating state, marine, and context factors}

Replicating the initial principle presented in Sect. 2.1.3, we use Saaty's table to compare the various geographical entities with respect to each criterion accounting for physical vulnerability. We apply the approach presented in Fig. 3 as follows:

\section{State factors}

For marine submersion, we determine the approximate radius of influence of marine submersion by crossing a digital elevation model with water levels or reference storm surge levels. In Languedoc-Roussillon and La Réunion, we use $2 \mathrm{~m}$ and $4 \mathrm{~m}$, respectively, as the reference water levels in the local terrestrial framework (LTF). At La Réunion, we obtained these values by summing the maximum tidal level (up to $0.4 \mathrm{~m}$ in the LTF), storm surge (including pressure and wind surges $(0.85 \mathrm{~m})$ ) and wave set-up and run-up (up to $2 \mathrm{~m}$ to $3 \mathrm{~m}$ for typical wave heights during a cyclone). In LanguedocRoussillon, the centennial water level used for the regulatory coastal risks plan is $2 \mathrm{~m}$. For the sea level rise scenario, we 


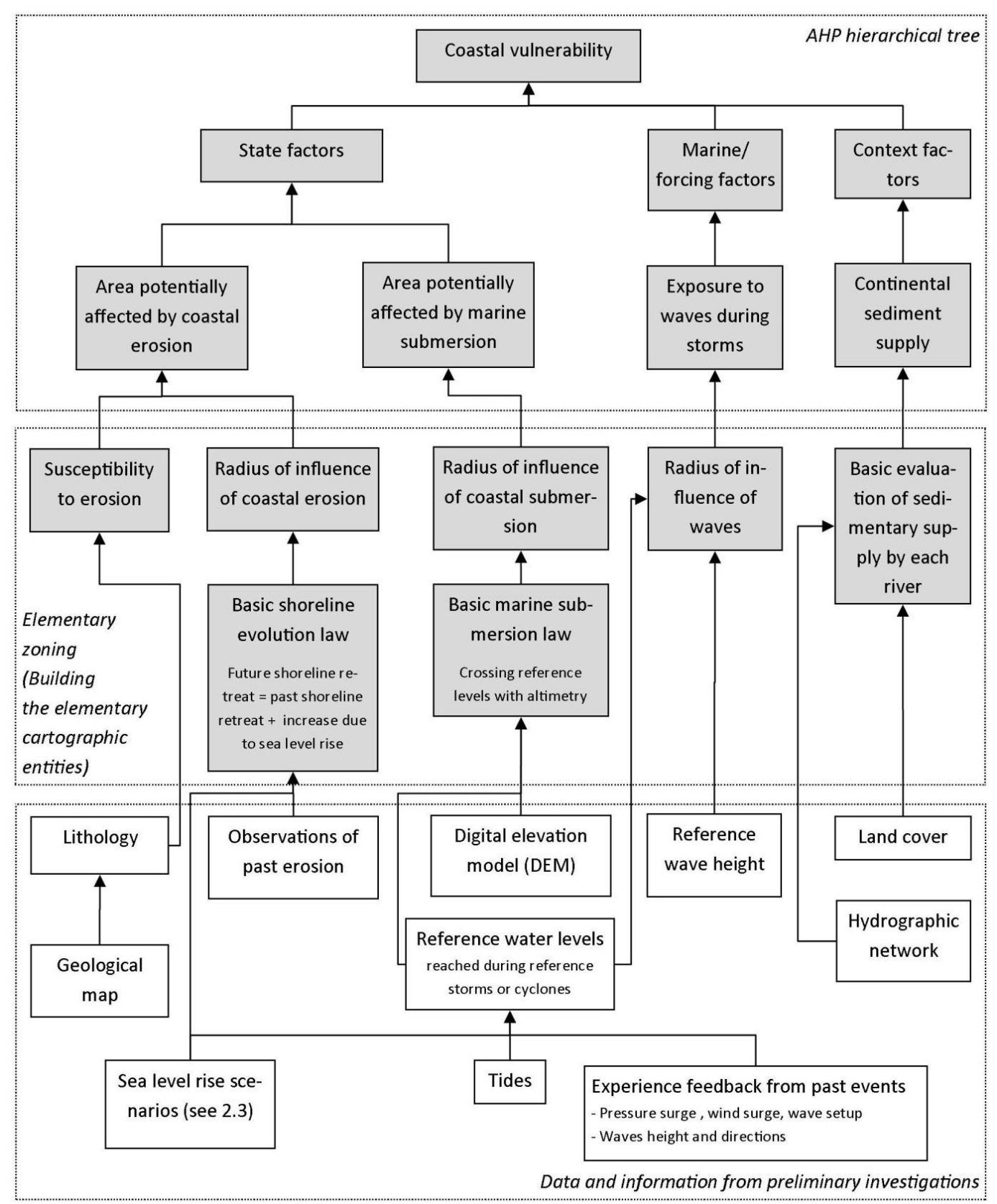

Fig. 3. Hierarchical tree and related elementary zoning used for the "sea level rise" scenario in Languedoc-Roussillon. A very similar tree was used for La Réunion (see Table 5 for a comparison of the two sites). In practice, most of the geoprocessing work consisted of defining elementary geographical spatial entities and rating them for each criterion.

raise these values by $1 \mathrm{~m}$. Then we introduce a scaling of uncertainties to take account of the uncertainties in DEM and low-lying area submersion processes.

To estimate coastal shoreline change, we apply simplified models and the associated scaling of uncertainties, taking into account the susceptibility of the coast to erode. We derive this information from the geological map. For example, in Languedoc-Roussillon, shoreline retreat will not occur in regions with Cretaceous rocks (as in the town of Sète), but will occur in regions with easily erodible sediments such as Holocene sands or mud deposits (Table 4).

The simplified model of beach erosion is the formula suggested by the Eurosion (2004) project, which combines expected erosion due to sea level rise (Bruun, 1962) with shoreline change due to ongoing processes, as calculated from past 


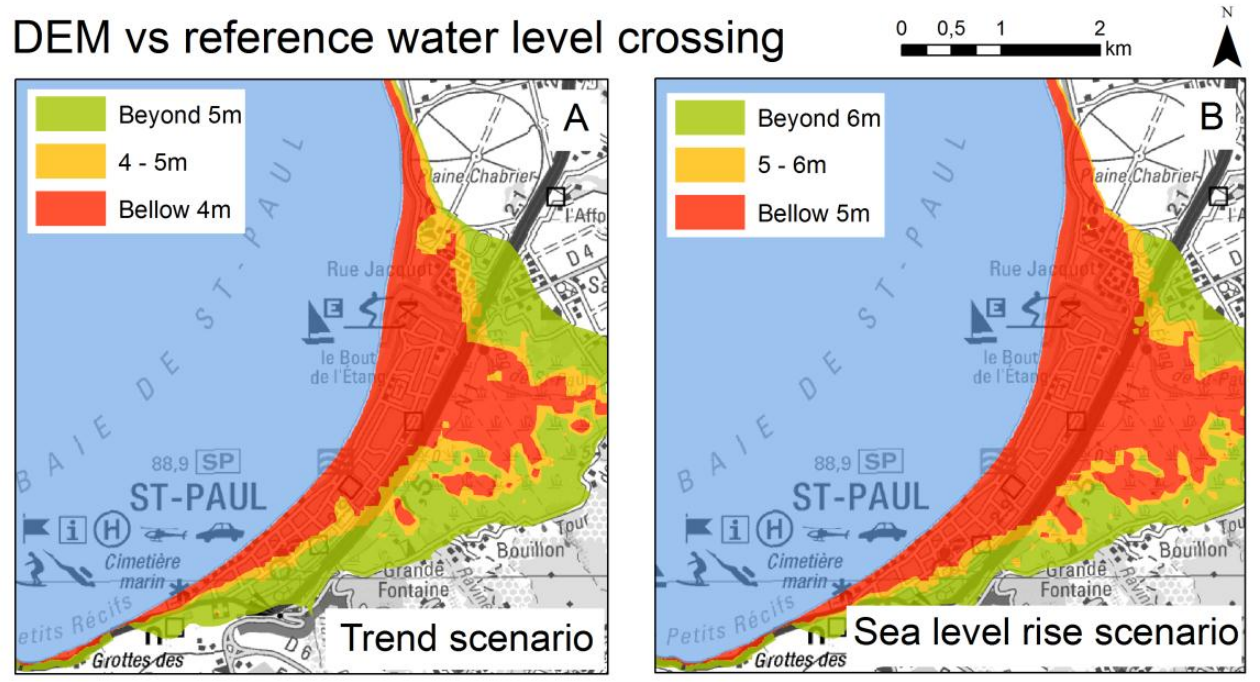

Coastal evolution (according to observed trends)
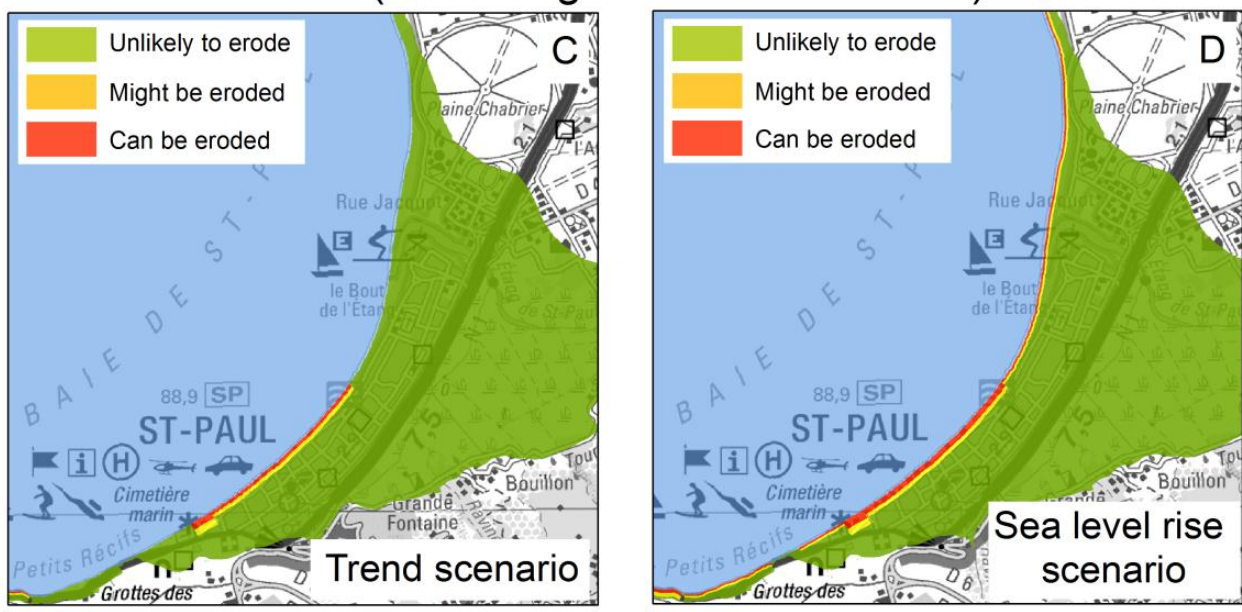

\section{Susceptibility to erosion}
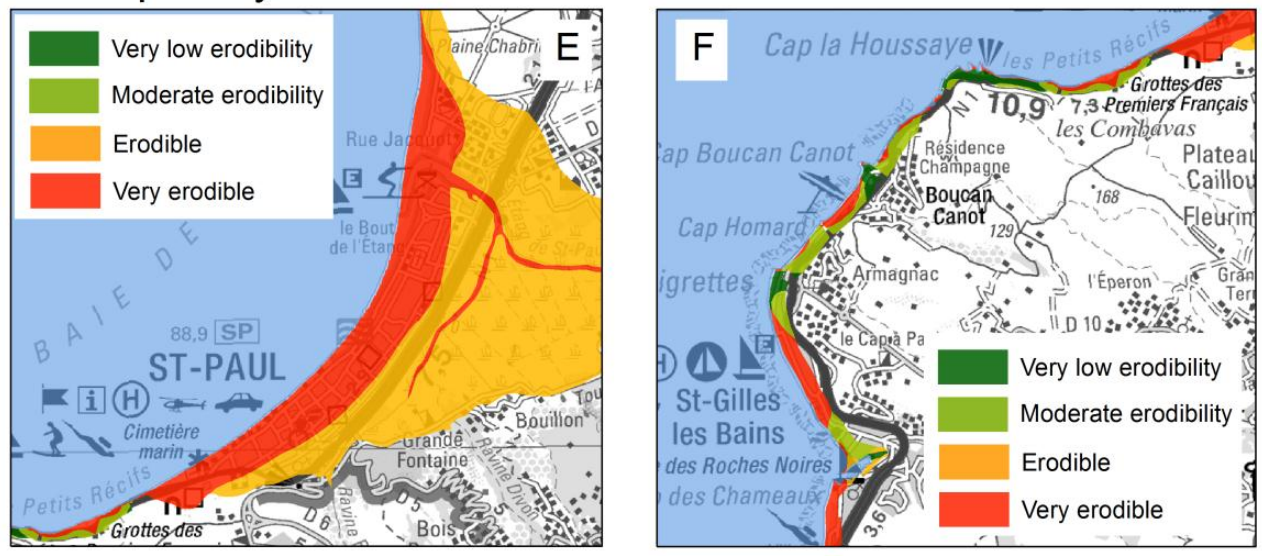

Fig. 4. Baseline geographical data used to estimate state factors: example in La Réunion near Saint-Paul (north-west). Submersion hazard risk is estimated in two scenarios by crossing reference water levels with a DEM (Maps A and B). Observed shoreline change is used to estimate how the shoreline may retreat in the future in the trend scenario $(\mathbf{C})$ and the sea leve rise scenario (D). Erodibility is estimated from geological maps (E). Another example of erodibility mapping to the south-west of Saint-Paul is given in map (F), showing erodible beaches surrounded by rocky spurs. (Data: BRGM, IGN). 
Table 4. A selection of geological classes and their associated erodibility and topography as derived for preparing the zonation. In LanguedocRoussillon, 170 different geological classes have been classified according to their susceptibility to erosion and typical topography (18 in La Réunion island).

\begin{tabular}{|c|c|c|}
\hline $\begin{array}{l}\text { Description of geology in the } 1: 50000 \\
\text { vectorised geological map }\end{array}$ & Typical topography (elicited) & Typical sensitivity to erosion (elicited) \\
\hline \multicolumn{3}{|l|}{ Languedoc-Roussillon } \\
\hline Alluvium (Recent or active) & Very low lying areas & Highly erodible \\
\hline $\begin{array}{l}\text { Aeolian decarbonated sandy dunes of } \\
\text { the Vendres plateau }\end{array}$ & Low lying areas & Highly erodible \\
\hline Lacustrine limestones (late Oligocene) & Hilly areas & Slightly erodible \\
\hline Present barrier beach & Very low lying areas & Highly erodible \\
\hline \multicolumn{3}{|l|}{ La Réunion island } \\
\hline Sandy beaches and dunes & - & Highly erodible \\
\hline Alluvium & - & Erodible \\
\hline $\begin{array}{l}\text { Pyroclastic materials, lahars, tuff, } \\
\text { screes }\end{array}$ & - & Moderately erodible \\
\hline Basaltic "flows" & - & Not erodible \\
\hline
\end{tabular}

shoreline observations:

$R_{\text {future }}=R_{\text {historical }}+\frac{S_{\text {future }}-S_{\text {historical }}}{\tan (\alpha)}$

where $\tan (\alpha)$ is the beach slope and $\mathrm{S}$ is the sea level rise. For cliff erosion we combine spatially continuous knowledge of past erosion, local knowledge of erosion rates calculated for a few representative sites and expert opinions (De La Torre et al., 2006). The use of these models is arguable (e.g. Cooper and Pilkey, 2004), so we consider a scaling of uncertainties in potential future erosion instead of a single future shoreline position (Table 2). We obtain the areas potentially affected by coastal erosion by cross-tabulating susceptibility to erosion with the probabilistic radius of influence of coastal erosion (Fig. 4).

\section{Marine factors}

We elaborate complementary marine factors in order to highlight the more important physical vulnerability in low-lying geographical entities in areas exposed to waves and surges. In Languedoc-Roussillon, this leads to increasing the vulnerability index where low-lying entities are close to lagoons or rivers. In La Réunion, we use the previous results of Lecacheux et al. (2012) to identify areas that can be affected by extreme waves from cyclones or southerly waves.

\section{Context factors}

Finally, to further refine the mapping of coastal vulnerability, we considered how the various coastal systems may be affected by changes in sediment supply from adjacent units. In Languedoc-Roussillon, we use watershed land use as an indicator of how human activities may have affected sediment transport from the watershed to the coastal zone. We assume that higher levels of urbanisation and, to a lesser extent, agriculture reduce the transport of coarse sediments to coastal areas. In this study, the Rhône delta is the most affected watershed, which is consistent with feedback from more quantitative analyses (Delmas et al., 2012). Similarly, in La Réunion, we consider the fact that the larger rivers are the main source of sediments, but that coral reefs also nourish some western beaches. This simplified approach produces an initial proxy for evaluating the availability of coarse sediments, but does not consider the subsequent coastal sediment transport processes, e.g. the effects of longshore northeasterly sediment transport induced by easterly trade waves in La Réunion island. This approach defines entities that are more likely to be resilient to worsening erosion due to the role of adjacent sedimentary units.

All of the qualitative assessments are evaluated using Saaty's correspondence table (Table 1) and calculations of scores from pairwise comparison matrices (similar to Table 2). Here, we calculated between 5 and 7 matrices per scenario and per study site, with size ranging from $3 \times 3$ to $7 \times 7$, depending on the number of classes considered for each criterion. We provide an example in Table 4, which illustrates how we classify the initial 170 geological classes in the $1: 50000$ geological map of the coastal zones of LanguedocRoussillon into 7 bins, leading to a $7 \times 7$ matrix defining an erodability index at each location.

\subsubsection{Weighting process, role of user groups, and exploitation of the results}

Finally, we integrate and aggregate the geographical features and the basic indicators defined above into an AHP hierarchical tree. Table 5 shows how we weighted the various criteria 
in the hierarchical tree, with the factor weighting resulting from an application of AHP.

One user group and two expert groups critically reviewed the resulting maps and weights (Fig. 1). The French Ministry of the Environment set up and coordinated the user group to ensure that the work undertaken to map coastal vulnerability would comply with the needs of coastal stakeholders. We set up the expert groups to help in the preliminary investigations, to monitor the adaptation of the AHP method, to review the vulnerability maps and the associated uncertainties, and ultimately to approve their dissemination. The experts compared the preliminary maps with their subjective understanding of coastal vulnerability in the region.

In order to estimate the potential social and economic impacts, previous studies developed indicators that combined physical and societal vulnerability, using, for example, population density data (e.g. McLaughlin et al., 2002; Hegde and Reju, 2007) or more detailed social surveys including factors such as employment, income, poverty, age, etc. (Boruff et al., 2005). Here, we simply identify a selection of "hotspots" by overlaying the physical vulnerability with the existing assets (current residential, tourist, harbour and industrial assets) as an illustrative example of a potential application of the physical vulnerability maps.

\subsubsection{Uncertainties}

Although uncertainties of multi-criteria mapping are difficult to quantify accurately, it is still possible to list them and to estimate qualitatively their significance (Bell and Glade, 2004). We provide this analysis in Table 6 for the two applications in Languedoc-Roussillon and La Réunion. One important source of uncertainty is the difficulty that the experts had in judging the relative importance of different factors at the highest levels of the AHP decision tree (e.g. relative importance of context factors with respect to marine or state factors). This difficulty is also acknowledged in other coastal vulnerability multi-criteria analyses. For example, Gornitz et al. (1991) chose a geometric aggregation in the coastal vulnerability index because it was considered to be the least sensitive to gaps in data. Here, the state factors were the most important criteria with respect to marine and context factors, with a difference of importance of intensity 4 on the Saaty scale. Nevertheless, similarly to Coelho et al. (2006), we tested other weighting options in a sensitivity analysis to help evaluate the significance of these uncertainties (Fig. 5). The results are less affected by a change of the weightings of the decision tree than by a change the initial sea level rise hypothesis. Table 6 also shows that many uncertainties arise from the limitations of the conceptual models used for evaluating future shoreline retreat and submersion. Finally, the question of spatial and temporal multi-scale dynamics was not addressed in this study.

\section{Results}

\subsection{Characteristics of resulting maps}

We provide examples of the resulting maps in Fig. 6. These maps represent the ranking obtained after applying the AHP to each geographical entity considered as geomorphologically and morphodynamically homogeneous. The results can be interpreted as a physical vulnerability index. Since the ranking is performed independently for the two sea level scenarios, the scales cannot be compared in Figs. 6a and b (respectively, $6 \mathrm{~d}$ and e). Therefore, we produced a third series of maps to show where physical vulnerability is expected to increase with sea level rise compared to the trend scenario (Figs. $6 \mathrm{c}$ and $\mathrm{f}$ ). Taking into account the uncertainties (Table 6), we estimated that the map resolution should be 1:50 000 for Languedoc-Roussillon and under 1:25000 for La Réunion.

Regarding the sea level rise scenarios in both regions, these maps reflect the fact that sea level rise is expected to increase erosion of beaches and soft cliffs and submersion of low-lying areas, especially those located close to lagoons. Comparing maps $6 \mathrm{a}$ and $\mathrm{b}$ (respectively, $6 \mathrm{~d}$ and e) shows that even without sea level rise, some portions of coastal areas are vulnerable to erosion and flooding. These conclusions are consistent with an intuitive analysis, but the added value of the maps presented here is that each location is assigned a physical vulnerability index, which can be used for land use planning. For example, when considering establishing new infrastructure with a multi-decadal design life, it is preferable to choose an area with a lower physical vulnerability index, notwithstanding other considerations (e.g. the economic or environmental advantages of a given location) and future improvements in the understanding of coastal hazard changes.

Depending on the implementation of adaptation strategies, some possible consequences of sea level rise in the most vulnerable areas are the loss of land, changes in land use, or increased costs for risk prevention. For example, some parts of the harbour in Sète (in Languedoc-Roussillon) and Le Port (in La Réunion) are shown to be highly vulnerable. However, in urban, industrialised or harbour environments, the main changes are expected to be caused by human activities and not climate change. The maps presented here indicate that according to current knowledge, these areas will likely be affected by more frequent degradations (e.g. due to flooding, erosion, scouring, sea wave pressure or the collection of debris in between them) resulting in higher maintenance costs.

\subsection{La Réunion island}

For both of the La Réunion scenarios, the results show the highest vulnerability in low-lying areas and areas immediately adjacent to the sea, particularly caused by coastal beach and cliff erosion. Compared to the trend scenario, the sea 
Table 5. Hierarchical tree and associated weighting used for Languedoc-Roussillon. The criteria weighting are obtained by applying AHP similar to the example in Table 2.

\begin{tabular}{llll}
\hline Factors & Factor weighting & Criteria & Criteria weighting \\
\hline Languedoc-Roussillon & & & \\
\hline State factors & 0.667 & $\begin{array}{l}\text { Area potentially affected by erosion } \\
\text { Area potentially affected by flooding }\end{array}$ & 0.5 \\
& & Exposure to waves during storms & 1 \\
Marine factors & 0.167 & External sediment supply & 1 \\
Context factors & 0.167 & & \\
\hline La Réunion & & Area potentially affected by erosion & 0.5 \\
\hline State factors & 0.667 & Area potentially affected by flooding & 0.5 \\
& \multirow{2}{*}{0.167} & Extreme events & 0.84 \\
Marine factors & \multirow{2}{*}{$\begin{array}{l}\text { Non-extreme coastal dynamics } \\
\text { Context factors }\end{array}$} & External sediment supply & 0.16 \\
\hline
\end{tabular}
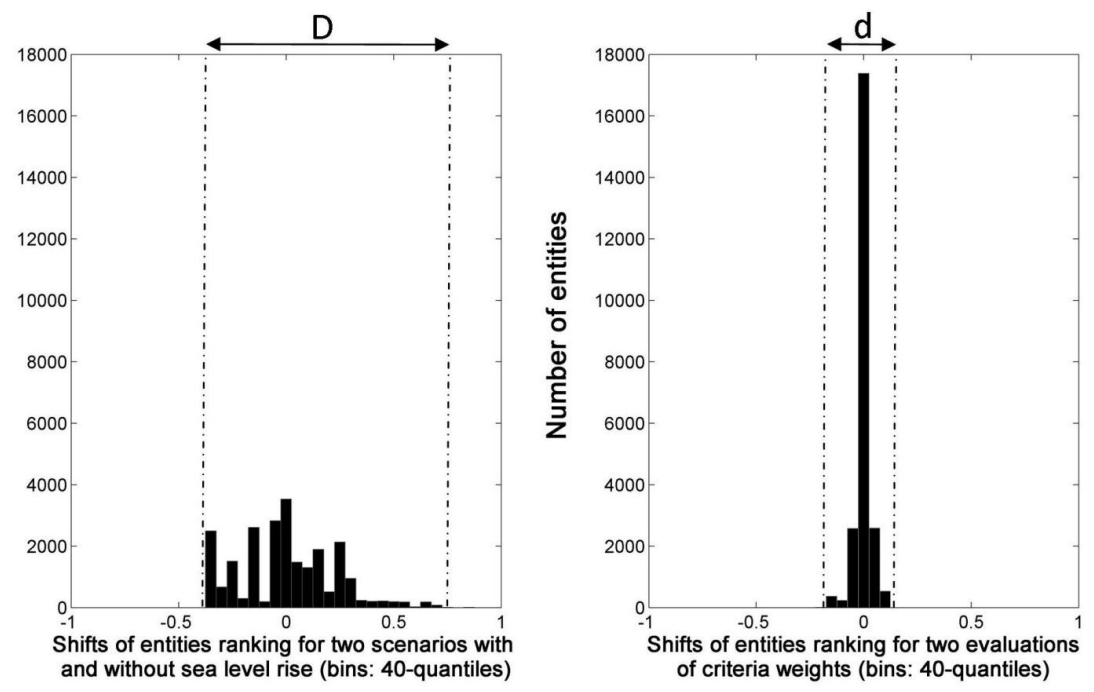

Fig. 5. Sensitivity analysis performed for La Réunion to compare the redistribution of entity rankings when the criteria weightings in Table 5 change according to the sea level rise (right) and trend scenarios (left). On the right, the criteria are considered either of equal weight or as in Table 5. This corresponds to the maximum acceptable range of criteria weighting. The largest spread in the left-hand histogram (D>d) shows that considering two scenarios causes more changes in entity ranking than modifying the criteria weights in Table 5. This sensitivity analysis is used to prepare the qualitative assessment of uncertainties in Table 6.

level rise scenario is characterised by increases in flooding hazards in these three areas, as well as by greater erosion of erodible cliffs and beaches (Fig. 6c).

We found that physical vulnerability is highest in the following areas (Fig. 7): Sainte Suzanne (north-east), SaintPaul, Le Port (north-west), the Etang-Sale (south), and in a number of more localised places adjacent to beaches (e.g. in Saint Pierre) or erodible cliffs (e.g. Saint Philippe). However, a first analysis of vulnerable assets highlights Le Port and Saint-Paul as the most impacted areas concerning the potential losses. In Saint-Paul, relatively low-lying and erodible areas are exposed to storms and cyclones because the coast is not protected from waves by an offshore coral reef.
However, the existing assets are presently considered to be located in sufficiently elevated areas to prevent flooding in most cases. In Le Port the industrial assets are located in an area affected by high rates of coastal erosion. Field surveys indicated that the nourishment of this area by river sediments is prevented by river and coastal work (Aubie and Oliveros, 1999). Other hotspots are distributed along the coast, including assets such as crops, buildings, roads, recreational pathways, and beaches (De La Torre et al., 2006; Blangy et al., 2010). 
Table 6. Qualitative assessment of uncertainties for physical vulnerability assessment in Languedoc-Roussillon (LR) and La Réunion (REU) (following the approach of Bell and Glade, 2004).

\begin{tabular}{|c|c|c|c|}
\hline Source of uncertainty & Uncertainty & Reason & Significance \\
\hline $\begin{array}{l}\text { Building the AHP } \\
\text { hierarchical tree }\end{array}$ & Medium & $\begin{array}{l}\text { The hierarchical tree is a simple but limited representa- } \\
\text { tion of the coastal system and its interactions (Figs. } 2 \\
\text { and } 3 \text { ) }\end{array}$ & Medium \\
\hline Elementary zoning & $\begin{array}{l}\text { High in LR } \\
\text { Very high } \\
\text { in REU }\end{array}$ & $\begin{array}{l}\text { Limitations of models, rough estimations, sparse data in } \\
\text { REU }\end{array}$ & Very high \\
\hline $\begin{array}{l}\text { Evaluating scores for each } \\
\text { criteria for each geographical } \\
\text { entity }\end{array}$ & $\begin{array}{l}\text { Medium in LR } \\
\text { Low in REU }\end{array}$ & $\begin{array}{l}\text { Insufficient resolution, accuracy and precision of some } \\
\text { datasets (e.g. MNT in LR), inaccurate relative position- } \\
\text { ing of data, heterogeneity of acquisition methods }\end{array}$ & Medium \\
\hline $\begin{array}{l}\text { Defining the weighting of } \\
\text { criteria and factors in the AHP } \\
\text { tree }\end{array}$ & Medium & $\begin{array}{l}\text { Some subjectivity. However, its significance remains } \\
\text { contained according to sensitivity analysis (Fig. 5) }\end{array}$ & Low to medium \\
\hline Expert validation & High & $\begin{array}{l}\text { Subjectivity. However, its significance remains limited } \\
\text { since the role of experts remains to provide rules and } \\
\text { data for the evaluation }\end{array}$ & Medium \\
\hline $\begin{array}{l}\text { Interactions between local and } \\
\text { regional processes }\end{array}$ & High & Not taken into account & Medium \\
\hline
\end{tabular}
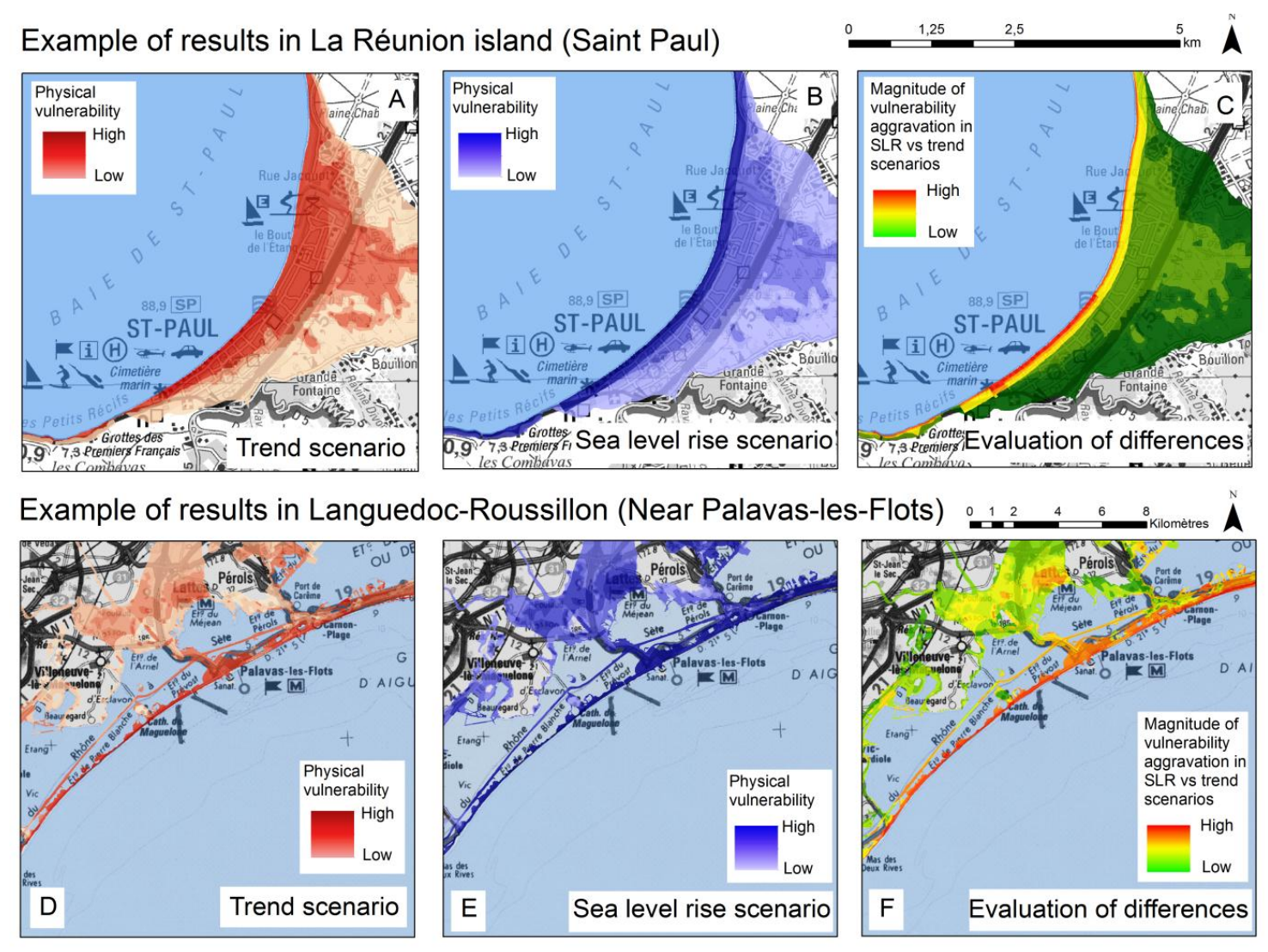

Fig. 6. Examples of results for La Réunion (Saint-Paul) and Languedoc-Roussillon (near Palavas-les-Flots). The maps are provided for 2 scenarios: sea level rise $(\mathbf{A}, \mathbf{D})$ and trend scenarios $(\mathbf{B}, \mathbf{E})$. Maps $\mathbf{C}, \mathbf{F}$ show areas where the physical vulnerability is expected to increase the most in the sea level rise scenario (Data: BRGM, IGN). 


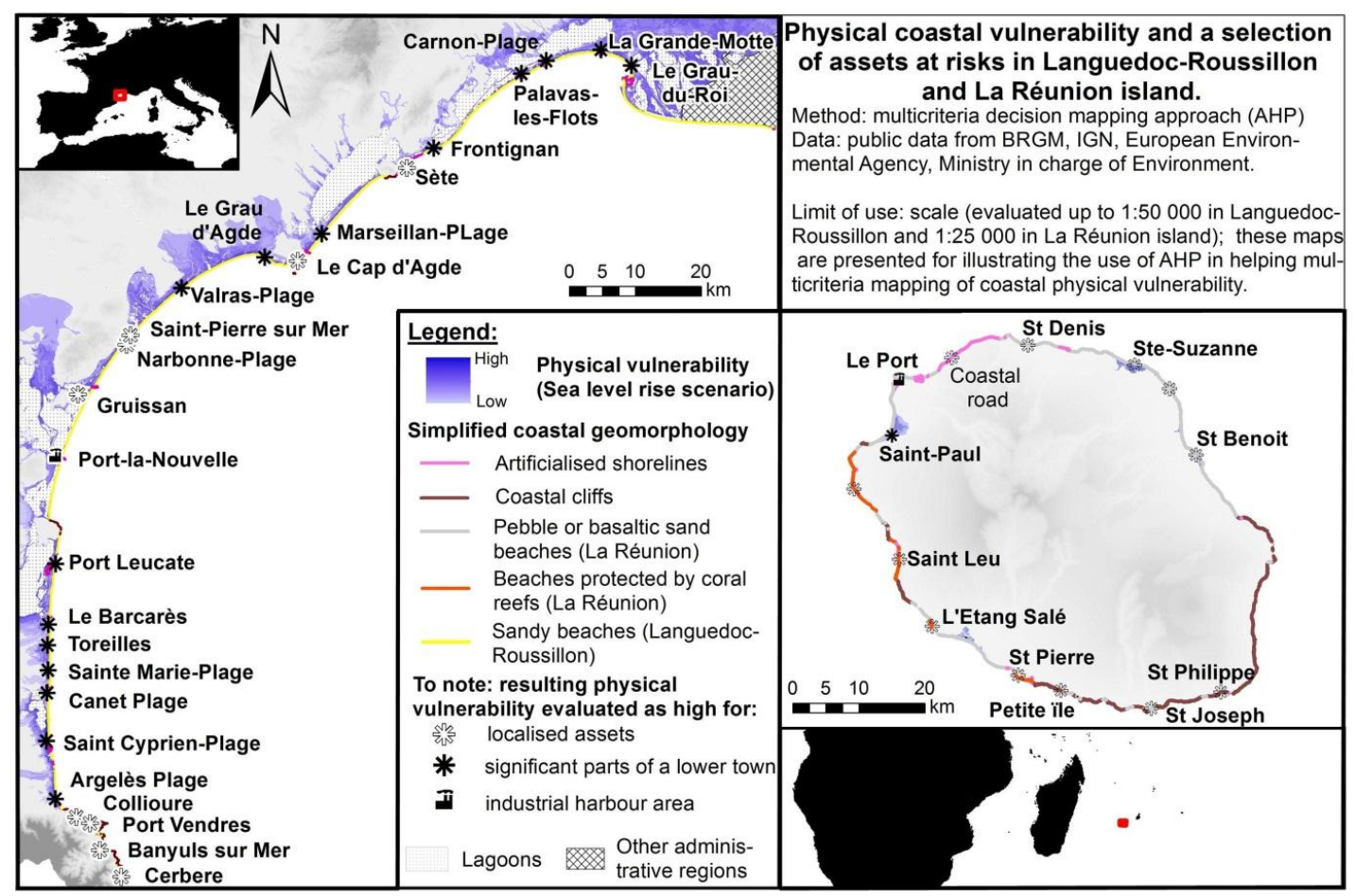

Fig. 7. Illustrative example of potential use of the resulting maps: cross tabulation of physical vulnerability with major assets in La Réunion and Languedoc-Roussillon.

\subsection{Languedoc-Roussillon}

In Languedoc-Roussillon, the trend and sea level rise scenarios both show the high physical vulnerability of lowlying areas (e.g. the shores of the Sigean and Leucate lagoons), sandbars (e.g. from Carnon to Frontignan), and deltas (Camargue). The maps also show that the river floodplains (i.e. recent sedimentary deposits) are most exposed to flash flood hazards, especially during heavy rainfall events combined (floods) with marine storm surges.

In many sand spits (e.g. east of Carnon-Plage), the maps show that lagoon and sea shores are vulnerable for two different reasons. The coastline facing the sea is most impacted by erosion, while the lagoon shoreline, lying no more than $1 \mathrm{~m}$ above sea level, is more impacted by submersion. The central part of sand spits (low sand dunes, sometimes affected by human activity and typically lying 2 to $3 \mathrm{~m}$ above mean sea level) appears to be the least vulnerable feature.

Figure 7 highlights the locations where high levels of physical vulnerability coincide with assets. The maps are quite similar to the earlier findings of Vinchon et al. (2009), with some differences in the identification of hotspots and their relative importance. For example, in this study, we only considered hotspots with major human infrastructure, while Vinchon et al. (2009) also considered assets of major environmental value (e.g. in the Camargue south of Le Grau du Roi). Regardless, both maps show high coastal vulnerabil- ity in this region, whatever the future implications of climate change may be.

\section{Discussion}

In order to analyse the benefits, limitations, and potential uses of the proposed approach, we evaluated the method using the criteria of Preston et al. (2011) in their generic recommendations for undertaking vulnerability mapping studies (Table 7).

\subsection{Benefits of the method}

\subsubsection{Integration of expert opinion}

When attempting to evaluate potential consequences of climate change in coastal areas, a first approach consists of directly assessing potential damages due to changing coastal erosion and flooding processes under the hypothesis of a certain rate of sea level rise (e.g. Hinkel and Klein, 2009). Such approaches are commonly expected to produce assessments of adaptation measures in terms of costs and benefits. When sufficiently high-value assets are at stake, and when future changes in coastal processes are well understood, such costbenefit analyses are useful (e.g. Hallegatte et al., 2011). However, in other cases, e.g. the coastal sites of this study, the uncertainties resulting from climate modelling, hazard and risk 
assessments, and economic estimations of potential damage can make these evaluations unreliable (Yates-Michelin et al., 2011).

In these cases, integrating expert opinions in the approach used to map future coastal vulnerability is highly important (e.g. Hanson et al., 2010). Here, AHP makes it possible to convert qualitative assessments of groups of experts into quantitative information that can be used to define the weighting of various criteria in multi-criteria analyses. Although achieving a consensus amongst members of user and expert groups is not easy, their involvement in our study (Fig. 1) was useful for identifying the remaining inconsistencies in weighting criteria and alternatives, and further improving the maps. In practice, this step does not allow the experts to create a new map as they wish because the results remain constrained by the basic data and the reference scale of the AHP method (Table 1). In addition, they need to support their opinions with data, observations or models. Finally, this work with expert and user groups helps to identify more accurately the most important uncertainties (Table 6). The ability of AHP to manage different degrees of conviction facilitates the integration of uncertainties associated, for example, with the future position of shorelines. To summarise, the main benefit of the proposed approach is its capacity to gather existing knowledge and existing datasets in a structured, consistent manner in order to map future coastal physical vulnerability.

\subsubsection{Transportability of the method}

We tested the method in two different contexts in terms of geodynamics and data availability. In practice, we were able to adapt the method to these two different contexts. The minimum data requirements for applying this method are the existence of coastal geomorphology data, historical erosion and accretion rates, and topographic data in the coastal zone. The geological map improves the final results: once the geological information is converted into information about the lithology, and thus the susceptibility to erosion, the final map inherits the geometry of the geological layer. However, this interpretation of the geological notations is not straightforward because it depends on the geological map and requires geological expertise. In particular, Holocene deposits must be accurately mapped. Therefore, we think that the approach can be transported to other coastal locations, provided there is sufficient data and the users accept its limitations and uncertainties.

\subsection{Limitations of the method}

We discuss below the limitations of this application of AHP in coastal vulnerability mapping by referring to the assessments of uncertainties (Table 6) and to the method as a whole (Table 7).

\subsubsection{Representation of the coastal system in an AHP-hierarchical tree}

First, the hierarchical framework (Fig. 3) only offers a limited representation of the conceptual graphs presented in Fig. 2: the hierarchical framework cannot handle interactions between criteria because it uses each criterion as an indication of the physical vulnerability of each geographical entity, regardless of potential relationships with other criteria. For example, in Languedoc-Roussillon, the context factors effectively provide a regional indication of where the sediment supply can compensate for erosion. This indicator is important as it links watersheds to coastal zones. However, we simply added it to the state factors, which use more detailed and local information on erosion, and no interaction between scales is modelled here. Implicitly, it is postulated that the combination of simple maps of criteria would average these interactions and produce a consistent picture of vulnerability at the regional scale. This limitation is inherent to the multi-criteria approach with additive aggregation schemes.

\subsubsection{Lack of data}

The second limitation relates to random uncertainties, i.e. those associated with a lack of data or with data quality. In this study, the existing datasets are heterogeneous in terms of quality, and their geometry (spatial precision and accuracy) is sometimes insufficient for detailed zoning. Some information is lacking: for example, the geological map does not provide any geotechnical information, which may be important for quantifying cliff susceptibility to erosion (Benumof and Griggs, 1999). We were also lacking data to analyse the consequences of fringing coral reef degradation and sea level rise on lagoon waves, currents, and shoreline dynamics (e.g. Storlazzi et al., 2011). In some cases, existing data presented some spatial inconsistencies: for example, the actual shoreline position differs between various GIS shoreline datasets in Languedoc-Roussillon. In this region, the differences in shoreline position according to the various geographical layers (e.g. geology, DEM, land cover, etc.) require substantial geoprocessing and can result in errors in physical vulnerability assessments when zooming to local scales. A similar difficulty arises from the fact that the vectorised geological map legends are inconsistent in different administrative departments. These random uncertainties could be reduced with new datasets. 
Table 7. Evaluation of the proposed method.

\begin{tabular}{|c|c|}
\hline Evaluation criteria (after Preston et al., 2011) & Application in this study \\
\hline Objective of the approach & $\begin{array}{l}\text { Mapping physical vulnerability to erosion and flooding } \\
\text { in the context of future sea level rise }\end{array}$ \\
\hline Utility associated with spatial analysis of vulnerability & $\begin{array}{l}\text { Local and regional vulnerability assessments are } \\
\text { requested by an environmental regulation framework }\end{array}$ \\
\hline Benefits for stakeholders & $\begin{array}{l}\text { Planning long-life infrastructures, forecasting long- } \\
\text { term development }\end{array}$ \\
\hline Potential risk associated with representing information spatially & $\begin{array}{l}\text { Misevaluation of vulnerability due to imprecise vulner- } \\
\text { ability scale, use of maps at too local scales (e.g. under } \\
1: 5000 \text { in La Réunion ) }\end{array}$ \\
\hline Determinants of vulnerability & See Fig. 2 \\
\hline Representation of spatial, temporal, and multi-scale dynamics & $\begin{array}{l}\text { Not satisfactorily addressed because of lack of data and } \\
\text { methods }\end{array}$ \\
\hline Methods for vulnerability assessment and mapping & Multi-criteria mapping structured with AHP \\
\hline Uncertainties assessment & $\begin{array}{l}\text { Qualitative assessment completed with sensitivity anal- } \\
\text { ysis (See Sect. 3.2.4) }\end{array}$ \\
\hline Validation of maps & Interactions with 2 expert groups of geomorphologists \\
\hline Intended audience & $\begin{array}{l}\text { Regional authorities in charge of implementing regional } \\
\text { scenarios }\end{array}$ \\
\hline Communicability of the results & $\begin{array}{l}\text { Interactions with a user group (coastal management } \\
\text { stakeholders of state and regional authorities) gathered } \\
\text { by the Ministry of Environment. }\end{array}$ \\
\hline Translation of vulnerability assessment into actions & $\begin{array}{l}\text { Existing environmental framework to support adapta- } \\
\text { tion to climate change, existing regulations on } \\
\text { adaptation and land use planning. }\end{array}$ \\
\hline
\end{tabular}

\subsubsection{Lack of knowledge}

The third limitation relates to the epistemic uncertainties, i.e. those due to unknowns in physical processes. First, the maps presented here remain regional evaluations that do not address the complexity of scale interactions and local processes, such as the regional consequences of localised sand spit changes. Secondly, our maps rely on a number of fundamental laws that produce a spatial representation of future coastal erosion and submersion. In this study, we partly compensated for the indiscriminate nature of these laws by introducing degrees of uncertainty and by taking susceptibility to erosion and submersion into account for each geographical entity. However, using these laws remains arguable and introduces spatial zoning uncertainties that are difficult to estimate. For example, recent studies propose more sophisticated approaches than the use of the Bruun rule, but they require more data and have presently been developed only for specific locations (e.g. Ranasinghe et al., 2012, 2013). As a summary, this limitation is related to the lack of commonly recognised methods to properly estimate the impacts of sea level rise on coastal processes.

\subsubsection{Limited range of hazards considered in this study}

Finally, this study uniquely focuses on coastal threats, while users also need information on other threats. Especially in La Reunion, "multi-hazard" or "multi-risk" approaches (e.g. Vecchia, 2001; Grünthal et al., 2006; Douglas, 2007) are necessary to favour the establishment of infrastructure and homes in areas where the overall threat is low, whether related to coastal erosion, marine flooding or other completely independent risks such as landslides, river flooding or even volcanism. Such approaches are currently applied in regulatory risk prevention plans, with a focus on present hazards.

\subsection{Potential use in adaptation policies}

Our resulting maps must be considered critically and could be improved upon with new knowledge or data. However, the expert groups judged them informative and relevant for stakeholders involved in long-term coastal planning, development and adaptation since they incorporate more knowledge about sea level rise vulnerability than many of the existing shorter-term coastal prevention plans. They may 
also offer additional support for local authorities making development decisions, particularly in low-lying areas.

Intergovernmental and European commitments require European countries to introduce climate mitigation and adaptation strategies. In France, "climate and energy plans" are implemented at the regional level, including adaptation measures that should be based on assessments of vulnerability to climate change. These plans should then feed into regulatory regional land use policies. One of the challenges of this process is to generate realistic scenarios in a context of high uncertainty.

From the decision-making perspective, one advantage of the approach presented here is its ability to generate multiple scenarios that can then be used in participatory approaches to develop adaptive measures. Coastal stakeholders may choose one or more of the scenarios produced here or use the proposed framework for creating their own scenarios taking account of additional relevant information. Based on the different assessments of vulnerability, they can then decide whether the proposed adaptation strategies are the most appropriate from the point of view of their robustness, reversibility, and potential short-term benefits (Hallegatte, 2009).

The short-term benefits of proposed adaptation strategies link adaptation with risk prevention. Our results support previous studies that stress the importance of introducing risk reduction strategies in low-lying coastal areas, especially for sand spits and around estuaries. In this context, an example of a "no regrets strategy" could be to limit new peri-urban settlements and tourist infrastructure in these areas. This process is complementary to regulatory coastal risk prevention plans that address shorter term timescales.

As well as "no regrets" strategies, exchanges with the user group highlighted the difficulties of imagining adequate adaptation measures for long-term planning. For example, in highly vulnerable and already urbanised areas such as Palavas-Les-Flots in Languedoc-Roussillon or Saint Paul in La Réunion, removing exposed assets is often not an acceptable option for stakeholders and citizens. It therefore seems that in many cases, the only remaining option is to maintain shorelines and protect them from submersion and erosion, whatever the cost.

\section{Conclusions}

Using an AHP-derived method, we evaluated and mapped physical vulnerability to erosion and submersion at regional scales, in two different settings. The main strength of the method is its ability to convert expert opinions into numerical values and to integrate quantitative and qualitative knowledge and data in a structured way. This is very useful for defining weightings in multi-criteria approaches when the overall problem is not well formalised, which is the case for assessments of coastal physical vulnerability. While the weaknesses of the approach as well as the epistemic and random uncertainties are recognised, the resulting maps were considered to be informative and useful for coastal managers responsible for long-term planning.

In practice, such approaches can provide a baseline for physical vulnerability assessments to support adaptation strategies. This study has shown that we are able to produce vulnerability maps that satisfy geomorphology expert groups. Along with other incentives and regulations (e.g. coastal risk prevention plans), this may result in further informing spatial planning policies in coastal areas and contribute to ongoing forward studies on climate change adaptation.

Acknowledgements. This study was funded by the French Environment Ministry through the Explore 2070 project, with additional support from the French Research National Agency (ANR) for the master's thesis of M. Méndez and the publication of this work (CECILE project: 'Coastal Environmental Changes: Impact of sea LEvel rise', under grant number ANR-09-CEP-001-01). DREALLR, the French 'Coastal Observatory', the Hérault Département and EID Méditerranée provided data for this study. We also used the SONEL database. We thank the three groups of experts and users for their useful inputs and comments, as well as Rodrigo Pedreros, Yann Balouin, Alexis Stépanian, Arnaud Blangy, and Ywenn De La Torre for their support. We also thank the two anonymous reviewers for their comments that helped to improve this paper.

Edited by: O. Katz

Reviewed by: two anonymous referees

\section{References}

Alpar, B.: Vulnerability of Turkish coasts to accelerated sea-level rise, Geomorphology, 107, 58-63, doi:10.1016/j.geomorph.2007.05.021, 2009.

Aubie, S. and Oliveros, C.: Evolution du trait de côte de 1950 à 1997 de la baie de la Possession à l'embouchure de l'Etang de Saint Paul, Ile de la Réunion. [Shoreline evolution from 1950 to 1997 in Possession Baya at Saint Paul swamp estuary, La Réunion island] BRGM/R 40780, 1999.

Ayalew, L., Yamagishi, H., Marui, H., and Kanno, T.: Landslides in Sado island, Japan: Part ii. GIS-based susceptibility mapping with comparisons of results from two methods and verifications, Eng. Geol., 81, 432-445, doi:10.1016/j.enggeo.2005.08.004, 2005.

Bell, R. and Glade, T.: Quantitative risk analysis for landslides - Examples from Bíldudalur, NW-Iceland, Nat. Hazards Earth Syst. Sci., 4, 117-131, doi:10.5194/nhess-4-117-2004, 2004.

Benumof, B. T. and Griggs, G. B.: The Dependence of Seacliff Erosion Rates on Cliff Material Properties and Physical Processes: San Diego County, California, Shore \& Beach, 67, 29-41, 1999.

Blangy, A., De La Torre, Y., Vaslet, E., Mallet, C., and Dewez, T.: Morphodynamique des littoraux de La Réunion. Phase 3 : Suivi et gestion de l'érosion côtière sur 12 sites identifiés comme sensibles, [Morphodynamics of coasts of La Réunion island, phase 3: 
Monitoring and management of coastal erosion over 12 sensitive sites] BRGM/RP-57431-FR, 2010.

Boruff, B. J., Emrich, C., and Cutter, S. L.: Erosion hazard vulnerability of US coastal counties, J. Coast. Res., 21, 932-942, doi:10.2112/04-0172.1, 2005.

Bruun, P.: Sea level rise as a cause of shore erosion, Journal Waterways and Harbours Division, 88, 117-130, 1962.

Cazes-Duvat, V. and Paskoff, R.: Les littoraux des Mascareignes entre nature et aménagement, [Mascarene coasts between nature and development] L'Harmattan, 186 pp., 2004.

Chakar, S.: Cartographie décisionnelle multicritères : formalisation et implémentation informatique. [Multicriteria decision mapping: Formalization and computer implementation.] Doctoral thesis, University of Paris Dauphine, 2006.

Chang, H.-K., Liou, J.-C., and Chen, W.-W.: Protection priority in the coastal environment using a hybrid ahp-topsis method on the Miaoli coast, Taiwan, J. Coast. Res., 28, 369-374, doi:10.2112/jcoastres-d-10-00092.1, 2012.

Chen, Y.-R., Yeh, C.-H., and Yu, B.: Integrated application of the analytic hierarchy process and the geographic information system for flood risk assessment and flood plain management in Taiwan, Nat. Hazards, 59, 1261-1276, doi:10.1007/s11069-0119831-7, 2011.

Coco, G. and Murray, A. B.: Patterns in the sand: From forcing templates to self organization, Geomorphology, 91, 271-290, http://dx.doi.org/10.1016/j.geomorph.2007.04.023, 2007.

Coelho, C., Silva, R., Veloso-Gomes, F., and Pinto, F. T.: A vulnerability analysis approach for the Portuguese West Coast, Wit Trans. Ecol. Envir., 91, 251-262, doi:10.2495/risk060241, 2006.

Cooper, N. J. and Jay, H.: Prediction of large scale coastal tendency: development and application of a quantitative behavior based methodology. Journal of Coastal Research, ICS 2002 proceedings, Special Issue 36, 173-181, 2002.

Cooper, J. A. G. and Pilkey, O. H.: Sea-level rise and shoreline retreat: Time to abandon the bruun rule, Global Planet. Change, 43, 157-171, doi:10.1016/j.gloplacha.2004.07.001, 2004.

Deboudt, P.: Towards coastal risk management in France, Ocean Coast. Manag., 53, 366-378, doi:10.1016/j.ocecoaman.2010.04.013, 2010.

Delmas, M., Cerdan, O., Cheviron, B., Mouchel, J.-M., and Eyrolle, F.: Sediment export from French rivers to the sea, Earth Surf. Proc. Landf., 37, doi:10.1002/esp.3219, 2012.

De La Torre, Y.: Synthèse morphodynamique des littoraux de La Réunion, état des lieux et tendances d'évolution à l'échelle de l'île [Synthesis of morphodynamics of La Réunion coasts: inventory and trends across the island], BRGM/RP53307-FR, 2004.

De La Torre, Y., Balouin, Y., and Dewez, T.: Morphodynamique des littoraux de La Réunion. Phase 2 : estimation de l'érosion côtière sur les sites identifiés comme sensibles [Morphodynamics of coasts of La Réunion island, phase 3 Monitoring and management of coastal erosion over 12 sensitive sites] BRGM/RP55014-FR, 2006.

Douglas, J.: Physical vulnerability modelling in natural hazard risk assessment, Nat. Hazards Earth Syst. Sci., 7, 283-288, doi:10.5194/nhess-7-283-2007, 2007.

Doukakis, E: Identifying coastal vulnerability to climate changes, J. Marine Environ. Eng., 8, 155-160, 2005.

Ercanoglu, M., Kasmer, O., and Temiz, N.: Adaptation and comparison of expert opinion to analytical hierarchy process for land- slide susceptibility mapping, Bull. Eng. Geol. Environ., 67, 565578, doi:10.1007/s10064-008-0170-1, 2008.

Eurosion: www.eurosion.org; last access: 16/06/2012, 2004.

Fairbank, H. and Jakeways, J.: Mapping coastal risk in a changing climate, Isle of Wight Centre for Coastal Environment, 2006.

Garcin, M., Poisson, B., and Pouget, R.: High rates of geomorphological processes in a tropical area: the Remparts River case study (Reunion Island, Indian Ocean), Geomorphology, 67, doi:10.1016/j.geomorph.2004.11.002, 2005.

Gornitz, V.: Global coastal hazards from future sea-level rise, Global Planet. Change, 89, 379-398, 1991.

Gorsevski, P. V., Jankowski, P., and Gessler, P. E.: An heuristic approach for mapping landslide hazard by integrating fuzzy logic with analytic hierarchy process, Control Cybern., 35, 121-146, 2006.

Grünthal, G., Thieken, A. H., Schwarz, J., Radtke, K. S., Smolka, A., and Merz, B.: Comparative risk assessments for the city of cologne - storms, floods, earthquakes, Nat. Hazards, 38, 21-44, doi:10.1007/s11069-005-8598-0, 2006.

Hallegatte, S.: Strategies to adapt to an uncertain climate change, Global Environ. Chang., 19, 240-247, doi:10.1016/j.gloenvcha.2008.12.003, 2009.

Hallegatte, S., Ranger, N., Mestre, O., Dumas, P., Corfee-Morlot, J., Herweijer, C., and Wood, R. M.: Assessing climate change impacts, sea level rise and storm surge risk in port cities: a case study on Copenhagen, Climatic Change, 104, 113-137, doi:10.1007/s10584-010-9978-3, 2011.

Hanson, H., Aarninkhof, S., Capobianco, M., Jimenez, J. A., Larson, M., Nicholls, R. J., Plant, N. G., Southgate, H. N., Steetzel, H. J., Stive, M. J. F., and de Vriend, H. J.: Modelling of coastal evolution on yearly to decadal time scales, J. Coast. Res., 19, 190-811, 2003.

Hanson, S., Nicholls, R. J., Balson, P., Brown, I., French, J. R., Spencer, T., and Sutherland, W. J.: Capturing coastal geomorphological change within regional integrated assessment: An outcome-driven fuzzy logic approach, J. Coast. Res., 26, 831842, doi:10.2112/jcoastres-d-09-00078.1, 2010.

Hegde, A. V. and Reju, V. R.: Development of coastal vulnerability index for the Mangalore coast, India, J. Coast. Res., 23, 11061111, doi:10.2112/04-0259.1, 2007.

Hinkel, J. and Klein, R. J. T.: Integrating knowledge to assess coastal vulnerability to sea-level rise: The development of the DIVA tool, Global Environ. Chang., 19, 384-395, doi:10.1016/j.gloenvcha.2009.03.002, 2009.

Lebbe, L., Van Meir, N., and Viaene, P.: Potential implications of sea-level rise for Belgium, J. Coast. Res., 24, 358-366, doi:10.2112/07a-0009.1, 2008.

Lecacheux, S., Pedreros, R., Le Cozannet, G., Thiébot, J., De La Torre, Y., and Bulteau, T.: A method to characterize the different extreme waves for islands exposed to various wave regimes: a case study devoted to Reunion Island, Nat. Hazards Earth Syst. Sci., 12, 2425-2437, doi:10.5194/nhess-12-24252012, 2012.

Lombard, A., Cazenave, A., DoMinh, K., Cabanes, C., and Nerem, R. S.: Thermosteric sea level rise for the past 50 years; comparison with tide gauges and inference on water mass contribution, Global and Planetary Change, 48, 303-312, doi:10.1016/j.gloplacha.2005.02.007, 2005. 
Malczewski, J.: GIS-based multicriteria decision analysis: A survey of the literature, Int. J. Geogr. Information Sci., 20, 703-726, doi:10.1080/13658810600661508, 2006.

McLaughlin, S., McKenna J., and Cooper J. A. G.: Socio-economic data in coastal vulnerability indices: constraints and opportunities, J. Coast. Res., ICS 2002 proceedings, Special Issue 36, 487497, 2002.

Meehl, G. A., Stocker, T. F., Collins, W. D., Friedlingstein, P., Gaye, A. T., Gregory, J. M., Kitoh, A., Knutti, R., Murphy, J. M., Noda, A., Raper, S. C. B., Watterson, I. G., Weaver, A. J., and Zhao, Z.C.: Global Climate Projections, in: Climate Change 2007: The Physical Science Basis. Contribution of Working Group I to the Fourth Assessment Report of the Intergovernmental Panel on Climate Change, edited by: Solomon, S., Qin, D., Manning, M., Chen, Z., Marquis, M., Averyt, K. B., Tignor, M., and Miller, H. L., Cambridge University Press, Cambridge, UK and New York, NY, USA, 747-846, 2007.

Meyssignac, B. and Cazenave, A.: Sea level: A review of presentday and recent-past changes and variability, J. Geodynam., 58, 96-109, 2012.

Nicholls, R. J. and Cazenave, A.: Sea-Level Rise and Its Impact on Coastal Zones, Science, 328, doi:10.1126/science.1185782, 2010.

Nguyen Mai, D., Babel, M. S., and Luong, H. T.: Evaluation of food risk parameters in the day river flood diversion area, Red River delta, Vietnam, Nat. Hazards, 56, 169-194, doi:10.1007/s11069010-9558-x, 2011.

Pal, I., Nath, S. K., Shukla, K., Pal, D. K., Raj, A., Thingbaijam, K. K. S., and Bansal, B. K.: Earthquake hazard zonation of Sikkim Himalaya using a GIS platform, Nat. Hazards, 45, 333377, doi:10.1007/s11069-007-9173-7, 2008.

Paskoff, R. P.: Potential implications of sea-level rise for France, J. Coast. Res., 20, 424-434, doi:10.2112/15515036(2004)020[0424:piosrf]2.0.co;2, 2004.

Preston, B. L., Yuen, E. J., and Westaway, R. M.: Putting vulnerability to climate change on the map: A review of approaches, benefits, and risks, Sustain. Sci., 6, 177-202, doi:10.1007/s11625011-0129-1, 2011.

Rahman, M. R., Shi, Z. H., and Chongfa, C.: Soil erosion hazard evaluation-an integrated use of remote sensing, GIS and statistical approaches with biophysical parameters towards management strategies, Ecol. Model., 220, 1724-1734, doi:10.1016/j.ecolmodel.2009.04.004, 2009.

Rahmstorf, S.: A semi-empirical approach to projecting future sealevel rise, Science, 315, 368-370, doi:10.1126/science.1135456, 2007.

Ranasinghe, R., Callaghan, D., and Stive, M. J. F.: Estimating coastal recession due to sea level rise: beyond the Bruun rule, Climatic Change, 110, 561-574, doi:10.1007/s10584-011-01078, 2012.

Ranasinghe, R., Duong, T. M., Uhlenbrook, S., Roelvink, D., and Stive, M.: Climate-change impact assessment for inletinterrupted coastlines, 3, 83-87, 2013.

Romieu, E., Welle, T., Schneiderbauer, S., Pelling, M., and Vinchon, C.: Vulnerability assessment within climate change and natural hazard contexts: revealing gaps and synergies through coastal applications, Sustain. Sci., 5, 159-170, doi:10.1007/s11625-0100112-2, 2010.
Saaty, T. L.: The Analytic Hierarchy Process. New York: McGraw Hill. International, Translated to Russian, Portuguese, and Chinese, Revised editions, Paperback (1996, 2000), Pittsburgh: RWS Publications, 1980.

Saaty, T. L.: Decision making with the analytic hierarchy process, Int. J. Services Sciences, 1, 1, 2008a.

Saaty, T. L.: Relative Measurement and Its Generalization in Decision Making Why Pairwise Comparisons are Central in Mathematics for the Measurement of Intangible Factors The Analytic Hierarchy/Network Process, RACSAM, 102, 2008, 251318, 2008b.

Sekitani, K. and Yamaki, N.: A logical interpretation for the eigenvalue method in AHP. Journal of the Operations Research, Soc. Japan, 42, 219-232, 1999.

Storlazzi, C. D., Elias, E., Field, M. E., and Presto, M. K.: Numerical modeling of the impact of sea-level rise on fringing coral reef hydrodynamics and sediment transport, Coral Reefs, 30, doi:10.1007/s00338-011-0723-9, 2011.

Slangen, A. B. A., Katsman, C. A., van de Wal, R. S. W., Vermeersen, L. L. A., and Riva, R. E. M.: Towards regional projections of twenty-first century sea-level change based on IPCC SRES scenarios, Climate Dynamics, 38, 10.1007/s00382-0111057-6, 2012.

Tsimplis, M. N., Marcos, M., and Somot, S.: 21st century Mediterranean sea level rise: Steric and atmospheric pressure contributions from a regional model, Global Planet. Change, 63, 105111, doi:10.1016/j.gloplacha.2007.09.006, 2008.

Vecchia, A. V.: A unified approach to probabilistic risk assessments for earthquakes, floods, landslides, and volcanoes, Proceedings of a multidiscipilinary workshop held in Golden, Colorado 1617 November 1999, Open-File Report 01-324, U.S. Geological Survey, 2001.

Vinchon, C., Aubie, S., Balouin, Y., Closset, L., Garcin, M., Idier, D., and Mallet, C.: Anticipate response of climate change on coastal risks at regional scale in Aquitaine and Languedoc-Roussillon (France), Ocean Coast. Manag., 52, 4756, doi:10.1016/j.ocecoaman.2008.09.011, 2009.

Wöppelmann, G., Miguez, B. M., Bouin, M. N., and Altamimi, Z.: Geocentric sea-level trend estimates from GPS analyses at relevant tide gauges world-wide, Global Planet. Change, 57, 396406, doi:10.1016/j.gloplacha.2007.02.002, 2007.

Yalcin, A.: GIS-based landslide susceptibility mapping using analytical hierarchy process and bivariate statistics in Ardesen (Turkey): Comparisons of results and confirmations, Catena, 72, 1-12, doi:10.1016/j.catena.2007.01.003, 2008.

Yates, M. L., Le Cozannet, G., and Lenotre, N.: Quantifying errors in long-term coastal erosion and inundation hazard assessments, Journal of Coastal Research, Proceedings of the 11th International Coastal Symposium, Special Issue 64, 260-264, 2011.

Yates-Michelin, M., Le Cozannet, G., Krien, Y., and Lenôtre, N.: Amélioration de la méthode RNACC : caractérisation des incertitudes relatives à la quantification des impacts de l'élévation du niveau marin, [improving the RNACC method: characterization of uncertainties in the quantification of the impacts of sea level rise], rapport final BRGM/RP 59405-FR, 2011.

Yin, J., Yin, Z., Wang, J., and $\mathrm{Xu}$, S.: National assessment of coastal vulnerability to sea-level rise for the Chinese coast, J. Coast. Conservation, 16, 123-133, doi:10.1007/s11852-0120180-9, 2012. 